\title{
3D OPTIKAI SZKENNELÉS IPARI ALKALMAZÁSA - ESETTANULMÁNY
}

\section{INDUSTRIAL APPLICATION OF THE OPTICAL 3D SCANNING - CASE STUDY}

\author{
Bera Bálint \\ Óbudai Egyetem Bánki Donát Gépész és Biztonságtechnikai Mérnöki Kar, \\ egyetemi hallgató, Magyarország 1081 Budapest, Népszínház u. 8.; \\ Tel. +36305911456 balintbera@gmail.com
}

\begin{abstract}
In the modern measuring technology, the optical 3D scanning is one of the most developing and most progressive topics. Sensors based on the principle of laser-triangulation, supplemented with the suitable software, could be not only alternatives of the traditional measuring devices, but they could be more usable in some situations. This article shows a case study about an industrial optical 3D scanner and its application.
\end{abstract}

Keywords: measuring technology, 3D scanning, manufacturing technology, GOM

\section{Összefoglalás}

Az optikai 3D szkennelés a modern méréstechnika egyik leggyorsabban fejlődő, leginkább elöremutató ágazata. A háromszögelés elvén alapuló, lézerfényt használó szenzorok, kiegészítve a megfelelő szoftverrel, nem csak alternatívái lehetnek a hagyományos eszközöknek, de olyan mérési feladatok is egyszerủen kivitelezhetők velük, amik korábban jóval több ráfordítást igényeltek. A cikk egy ipari felhasználású optikai 3D szkenner alkalmazására mutat példát.

Kulcsszavak: méréstechnika, 3D szkennelés, gyártástechnológia, GOM

\section{Bevezetés}

A modern ipar egyik legfontosabb alappillére a méréstechnika, amely nélkül nem létezhet megfelelö minőségben sem a tervezés, sem a gyártás. A 21. századi minőségbiztosítási rendszerek, illetve az egyes iparágakra (főleg az autóiparra és a repülőgépiparra) jellemző, szerteágazó beszállítói láncok minden korábbinál jobban megkövetelik a cégektől modern és jól használható méréstechnikai apparátus kiépítését. A korszerü, nagypontosságú gyártási eljárások és az olyan különleges technológiák végtermékei, mint a robbantásos fémmegmun- kálás [1], illetve a modern müszaki müanyagokból fröccsöntött alkatrészek, sok esetben csak úgy mérhetőek hatékonyan, ha rendelkezésre áll a teljes felületüket vizsgálni képes eszköz. A megoldást a koordináta-méréstechnika jelenti, azon belül is a folyamatos letapogatású, idegen kifejezéssel szkenning-elvü rendszerek. Ezek közös jellemzője, hogy a mérendő objektumok teljes felületén végighaladnak, amivel nagyságrendekkel több ponton ellenőrizhetővé válnak az elöírt paraméterek. Ez egyben azt is jelenti, hogy jelentős mennyiségü adattal kell dolgozni, ami magával vonja a megfelelő számítástechnikai háttér meglétét. 
A 3D szkennereknek több változata is létezik, amiket méretük, pontosságuk, és müködési elvük szerint is csoportosíthatunk. Utóbbi szempont alapján különítjük el az optikai 3D szkennereket, amik a háromszögelés [2] és a kontrasztrács-vetítés [3] segítségével, érintkezés nélkül képesek egy tárgyat digitalizálni.

Említést érdemel, hogy a méréstechnikai felhasználás mellett igen elterjedt az optikai 3D szkennerek alkalmazása az úgynevezett „,reverse engineering” folyamatokban [6].

\section{Optikai 3D szkennerek az iparban}

Az optikai 3D szkennerek az 1980-as években jelentek meg, ám csak az 1990-es évek közepére fejlődtek odáig, hogy ipari viszonyok között is alkalmazhatóak legyenek. Ehhez leginkább a felbontóképességük és a méréstartományuk megfelelő szintje, valamint a hozzájuk tartozó mérőszoftverek megjelenése kellett.

Napjainkban már számos vállalat gyárt optikai 3D szkennereket kifejezetten ipari felhasználók számára. Ezek közös jellemzői a kompakt, egyszerü felépítés, a könnyü kezelhetőség, és a minőségbiztosítási folyamatokba való egyszerű integrálhatóság.

Általános tendencia, hogy egy mérörendszer-gyártó többféle méretben is kínálja termékeit, amik azonban egyazon séma szerint épülnek fel. Ez különösen abban az esetben hasznos, ha egy felhasználó bővíteni szeretné az apparátusát, ugyanis megspórolható a betanulási idő, és a már megvásárolt szoftverek is használhatók lesznek az új eszközzel. Erre a stratégiára mutat kiváló példát a német GOM GmbH. ATOS (Advanced Topometric Sensor - fejlett topometriás szenzor) termékcsaládja. Ennek legkisebb tagja igen csekély méretü, néhány milliméteres kiterjedésü objektumokat is képes $0,001 \mathrm{~mm}$ pontossággal digitalizálni, a legnagyobb pedig akár gépjármükarosszériák gyártósori vizsgálatára is alkalmas (1. ábra).

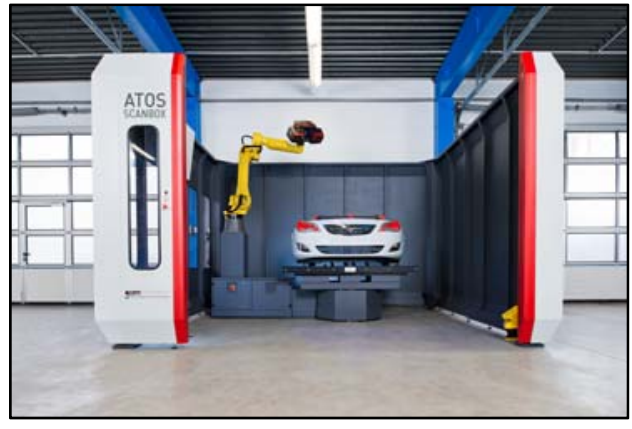

1. ábra. Gépjármü karosszéria mérése optikai 3D szkenner segitségével [4]

$\mathrm{Az}$ 1. ábrán látható, optikai $3 \mathrm{D}$ szkenneren alapuló mérőrendszer esetében az teszi lehetővé a gyors és pontos mérést, hogy egy új objektum digitalizálásakor azt mindig ugyan abba a pozícióba helyezik. Ezáltal a mérést végző személynek elég egyszer manuálisan végig vezetni a szenzort (mérőfejet) a vizsgált felületeken. A rendszerhez tartozó szoftver ugyanis képes megjegyezni az adott felvételekhez tartozó szenzor-pozíciókat, ezek segítségével pedig a későbbiekben automatikusan elvégzi a szkennelést.

Hasonló mondható el magáról a mérésről is. Az optikai 3D szkennerek szoftverei a kapott pontok alapján poligonhálót (nem átfedő háromszögekből álló hálót) hoznak létre a testről. Ezen különböző elemeket vehetünk fel a geometria leírására (síkok, pontok, hengerek, stb.), majd segítségükkel meghatározhatjuk a kívánt paramétereket (átmérők, szögek, stb.). A szükséges méreteket azonban elég csak egyszer definiálnunk: nagyobb minták esetén a szoftver minden új darab poligonhálóján képes ezek generálására, így a hagyományos eszközökhöz képest sokkal gyorsabbá válik a mérés. A 2. ábrán egy rádiusz mérése látható optikai $3 \mathrm{D}$ szkennerhez tartozó szoftverben, illeszkedő henger segítségével. 


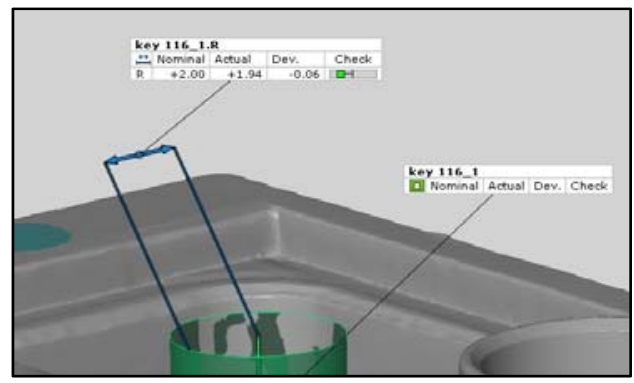

2. ábra. Rádiusz mérése illeszkedő henger segitségével, poligonhálón

A technológia legnagyobb elönye azonban mégsem a geometriai méretek gyors és pontos ellenőrzésében rejlik, hanem a teljes felületek összehasonlító vizsgálatában. Ennek során a már említett poligonhálót vetjük össze valamilyen etalonnal. Utóbbi lehet egy neutrális formátumú CAD-modell, vagy egy „hamis” CADmodell, amit egy másik alkatrész poligonhálójából képeztünk a mérőszoftver segítségével. Az összehasonlítás során a rendszer színekkel érzékelteti az eltéréseket, amelyek értékét jelölőkkel számszerüsíthetjük (3. ábra). A módszer különösen alkalmas fröccsöntött alkatrészek vizsgálatára, ugyanis jól kimutathatóak vele a sorják vagy beszívódások, amik az ilyen munkadarabok tipikus hibái [5].

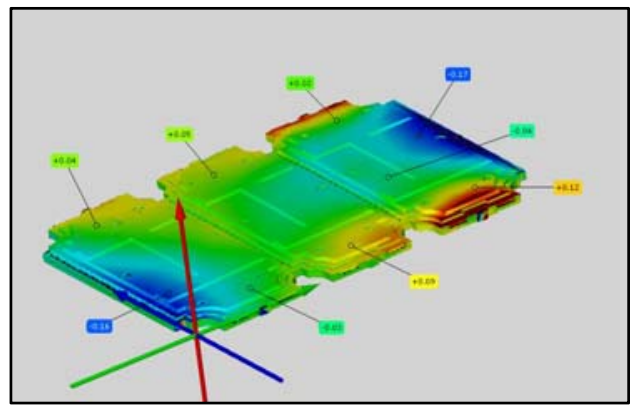

3. ábra. Poligonháló összevetése CAD modellel, felület összehasonlitás parancs segitségével GOM Inspect Professional szoftverben
Általánosságban tehát elmondható, hogy az optikai 3D szkennelés egy széleskörüen alkalmazható, az ipari feladatokba jól integrálható mérési technológia. A következőkben egy esettanulmány keretében mutatom be egy lehetséges alkalmazását, bizonyítandó a fenti állítás helyességét.

\section{Esettanulmány}

Az esettanulmányban egy fröccsöntött műanyag alkatrész (4. ábra) mérését mutatom be, GOM ATOS Core 200 optikai 3D szkenner, valamint a hozzá tartozó GOM ATOS Professional és GOM Inspect Professional mérőszoftverek segítségével.

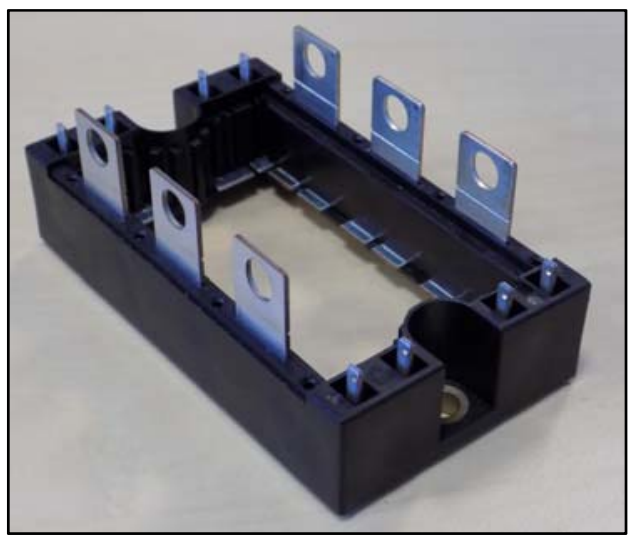

4. ábra. $A$ vizsgált alkatrész

Az alkatrész mérése annak kapcsán vált szükségessé, hogy a gyártását végző szerszámot lecserélték, amivel egy időben új beszállítóhoz is került. A vizsgálat célja az volt, hogy kiderüljön, van-e eltérés az új szerszámmal készült darabok és a korábbiak között.

A mérési körülmények szempontjából fontos, hogy a müanyag alkatrész több, beépülő fém elemet tartalmaz, amik fényvisszaverő tulajdonságaikat tekintve eltérőek. Ezért szükségessé vált speciális, tükröződésgátló anyag felvitele, ami a felü- 
letek kontrasztviszonyait közel azonossá tette.

A kezdeti elképzelés szerint az összehasonlító mérést hagyományos, érintéssel dolgozó koordináta-mérőgéppel végezték volna el, ám végül az optikai 3D szkennelés mellett született döntés. Ennek két oka volt. Egyrészt, az új szerszámmal készült mintákon felfedezhetőek voltak olyan kilökőnyomok, amik a korábbiakon nem, ezért célszerünek tünt részletes felületösszehasonlítást végezni. Másrészt, a termék fejlesztői elöírtak felületre vonatkozó alaktürést, amit legkönnyebben optikai 3D szkenneléssel lehet vizsgálni.

A szkennelési stratégiát ebben az esetben elsősorban az határozta meg, hogy szükséges volt a felület tükröződésmentesítése, illetve az a tény, hogy két felvétel-sorozatot kellett készíteni annak érdekében, hogy a teljes geometria rendelkezésre álljon.

Problémát egyedül az alkatrész oldalain látható, szük hornyok jelentettek, ezek mélységét később más módszerrel kellett megmérni. Ezen kívül minden más paramétert sikerült kellő pontossággal vizsgálni.

A mérés eredményeinek elemzése során fény derült rá, hogy több olyan pozíciótürés sem teljesül, amik korábban megfeleltek az elöírtaknak. Mivel ez már a mért darabok beépítése, az alkatrész összeszerelése előtt kiderült, sikerült megelőzni jó néhány selejtet a gyártási későbbi fázisaiban.

Szintén sikerült vizsgálni az említett profil-alaktürést, illetve számszerüsíteni a fröccsöntési hibák értékét. Ezt követően, a beszállítóval együttműködve, kijavításra került a fröccsöntő szerszám.

A javítások után újabb minta érkezett bemérésre, amiket a korábban megszokottnál jóval gyorsabban lehetett bemérni, ugyanis a szkennelés után mindössze le kellett generálni a korábban felvett méreteket az új poligonhálókra. Bebizonyosodott, hogy a mérések alapján eszközölt változtatások helyesek voltak, és a termék beveze- tése a sorozatgyártásba az előre tervezett időpontban elérhetővé vált. Ebben egyértelmü szerepe volt az optikai 3D szkenneléssel végzett méréseknek.

\section{4. Összegzés}

Az optikai 3D szkennelés szerepe a modern méréstechnikában megkérdőjelezhetetlen. Mára az iparban széleskörüen elterjedté vált, ezért érdemes és fontos nagy figyelmet fordítani rá. A tanulmányban bemutatásra kerültek a technológia leginkább előremutató elönyei, valamint egy esettanulmány keretében a konkrét alkalmazására is láthattunk példát. Ez alapján megállapítható, hogy az optikai 3D szkenneléssel dolgozó mérörendszerek kezelése nagy szakértelmet igényel, azonban ennek megléte esetén kiváló alternatívája lehet a hagyományos mérőrendszereknek, sőt, egyes esetekben ki is válthatja azokat.

\section{Szakirodalmi hivatkozások}

[1] Tünde Kovács-Coskun: Explosive Surface Hardening of Austenitic Stainless Steel. 3rd International Conference on Competitive Materials and Technology Processes. Miskolc-Lillafüred, 2014.

[2] Jens Gühring: 3D-Erfassung und Objektrekonstruktion mittels Streifenprojektion. Institut für Photogrammetrie der Universität Stuttgart. Stuttgart, 2002.

[3] Heinz-Jürgen Przybilla: Streifenprojektion Grundlagen, Systeme und Anwendungen. Hochschule Bochum, Fachbereich Vermessung und Geoinformatik. Bochum, 2014.

[4] http://r-design.hu/hu/atos-scanbox-merocella (letöltve: 2017.02.02.)

[5] Czvikovszky Tibor, Nagy Péter, Gaál János: A polimertechnika alapjai. Kempelen Farkas Hallgatói Információs Központ. Budapest, 2007.

[6] Horváth Richárd, Laczik Bálint, Zentay Péter: Application of Reverse Engineering in Manufacturing Design and Technology. XXV. International Scientific Conference. Miskolc, 2011. 